УДК 398.21(497.742)(049.3)

https://doi.org/10.55302/MF2077-78221vr

Ана Витанова-Рингачева

\title{
СЕМАНТИЧКИОТ ПОТТЕКСТ НА ЛОКАЛНАТА СКАЗНА ВО СООДНОС СО УНИВЕРЗАЛНИОТ МОДЕЛ НА СКАЗНОВИДНАТА МАТРИЦА \\ (врз примери од необјавената книга „Араптази - волшебни народни приказни од Струмица и Струмичко“ од Иван Котев)
}

\begin{abstract}
Апстракт: Фолклорот е највредното културно наследство што ни го оставиле нашите претходници во наследство. Неговото толкување и разгледување, па и компаративно расчленување е невозможно да се случи ако се разгледува само во границите на еден народ, на една држава. Научниот пристап подразбира, меѓу другото, и детекција и толкување на семантичкиот поттекст. Митолошката семантика е појдовната точка во толкувањето на сказната затоа што космичките закони за устројството на човекот и на светот во сказната се прелеваат кон социјалното и кон индивидуално искуство. Тотем-митовите за чудесните животни, за бракот и искушенијата, за стекнување необични нешта, најчесто волшебни предмети, за обредот на посветување, за патувањето во други светови и потрагата по лек за одредена болест, како и многу други мотивски конструкции, имаат свои реликти во сказната. Волшебните народни приказни се најколоритни, мотивски најбогати и најраскошни единици на фолклорот и тие се сметаат за највпечатлив вид усна проза. Регионот на Струмица и околината изобилува со фолклорна граѓa, особено со волшебни народни приказни, кои, по својата структура, мотивска конструкција и старост, се пресликуваат во универзалниот модел на светската сказна.
\end{abstract}

Клучни зборови: фолклор, сказна, универзален модел, Струмица.

Регионот на градот Струмица и околината, набљудуван од аспект на фолклористичките, етнографските и етнолошките истражувања е регион во кој многу малку е вложено и извадено на површина. Најмалку истражуван, а со уште помалку објавен оригинален фолклористичко-етнографски материјал, Струмичкиот Регион сѐ уште претставува неосвоена тврдина за истражувачите. Најголемиот подвиг, кога зборуваме за овој регион, веќе пет децении го прави современиот собирач, фолклорист и истражувач на фолклорот, Иван Котев. Покрај досега објавените книги од областа на фолклорот $^{1}$, највредното дело допрва треба да биде објавено. Станува збор за

\footnotetext{
${ }^{1}$ Иван Котев е автор на осум исклучително значајни книги за фолклорот од Струмица и од Струмичко, а овие се книги со немерлива вредност во македонската фолклористика воопшто: 1. Черешница род родила (Македонски народни песни, испеани од Савета Котева). (1984). Скопје: Институт за фолклор „Марко Цепенков“; 2. Енции Менци (Брзозборки, бројалки и залагалки за деца). (2002). Скопје: Детска Радост; 3. Македонски народни приказни, избор и редакција Иван Котев. (2007). Скопје: Детска Радост; 4. Мудроста на вековите (Македонски народни пословиии и
} 
големата книга со волшебни народни приказни од Струмица и регионот, насловена „Араптази“ .

Нашата посветеност на неговото дело сѐ повеќе добива димензии на подвиг, кој некаде, на некоја маргина, историјата можеби ке го запише. И тоа ни дава право да бидеме горди што сме сведоци на времето во кое живее и твори Иван Котев и што го сведочиме големиот јубилеј, 80 години живот и 50 години творештво. Во време на некои чудни тенденции, кои одат во насока да се обезвредни фолклорот или едноставно да му се придодаде пејоративен предзнак, Иван Котев донкихотски им пркоси на немилосрдните замавнувања на огромните ветерници. Многу ќе беше лесно тој да се откаже од својата мисија и одејќи по линија на помал отпор, да го остави објавувањето на делото за некои подобри времиња. Историјата покажала дека подобрите времиња се само имагинарна претстава за тоа каква иднина сакаме, но вистинското прашање е дали доволно силно се бориме за тоа. Иван Котев, не чекајќи ги тие времиња одеше и по време и по невреме, наоѓаше, отворени, полуотворени, но и затворени врати и на крајот, речиси секогаш успеваше да го распее или расприкаже информаторот. За егзистенцијата на фолклорното дело, предуслов е постоењето на група, којашто го прима и го одобрува, заклучува Роман Јакобсон. Токму таа група е најверниот слушател, пресоздател и преносител на пораките што, сам по себе, ги поседува фолклорот. Научното толкување на фолклористичката граѓа што ни е оставена во наследство, но и онаа што допрва треба да се ископа, значи и прилагодување на современите текови, кои бараат темелен семантички пристап. Своевремено, Владимир Проп тврдеше дека сказничните мотиви се, длабоко општествено, обусловени и историски засновани, предупредувајќи дека приказната не е хроника и дека грешат оние што бараат крилести змејови во праисторијата. И, ако проучувањето на сказната може да се случува врз основа на сличноста меѓу појавите, тогаш може истражувањата да се базираат и на различностите.

Покрај општествениот, историскиот и антрополошкиот пристап во разоткривање на вистината за сказната, сметаме дека нејзината структура поседува своја сопствена семантичка симболика. Ваквиот пристап подразбира откривање на смислата на искажувањето (нарацијата - ако зборуваме за прозните записи), бидејќи како што вели Борев, секоја информација пренесена преку јазикот, како знаковен систем, има своја содржина и свое значење. Токму толкувањето на смисловниот аспект на зборовите „и расчистувањето на просторот околу нив“, доведува до согледување на повеќезначните симболи што ги носи, во себе, зборот и воопшто, мислата.

поговорки од Струмица и Стримичко). (2012). Струмица; 5. Опеана Струмица (Народни песни од Струмица и Струмичко). (2016). Струмица; 6. Играле моми по месечина (Еротска народна поезија и проза од Струмииа и Струмичко). (2018). Струмица; 7. Туруниула Каравлашки. (Македонски епски народни песни од Струмица и Струмичко). (2018). Струмица; 8. Девојчето со златно срие (македонски народни волшебни приказни од Струмица и Струмичко. (2019). Струмица. 
На почетокот на XX век, руските футуристи, во поезијата, ја воведоа заумноста како дел од творечкиот процес, која значи семантичко соголување на текстот. Можеби оваа споредба и не е сосема оправдана, но од аспект на постапката, која сакаме да ја примениме врз сказната (како жанр што е во фокусот на нашето истражување), тогаш семантичкото соголување на сказната е единствениот начин за откривање на заумниот јазик, кој, народниот раскажувач, можеби несвесно, но многу вешто го користел. Сказната претставува едно глобално, универзално книжевноисториско творечко искуство низ кое поминал човекот како индивидуа, но и човештвото како колектив.

Имајќи го предвид фактот, што Струмичкиот Регион е истражуван најмалку, а уште помалку има објавено оригинален фолклористичкоетнографски материјали, изборот што го приложува Иван Котев претставува огромен влог за подобрување на наведената состојба. Струмичкиот Регион претставува неисцрпен извор на фолклористички материјал, кој, за жал, не е доволно публикуван. Собирачката активност на нашиот современ фолклорист Иван Котев подразбира децениско теренско истражување, потрага по информатори, запишување, архивирање и дешифрирање на фолклористичката граѓa. Фолклористичките единици од книгата „Арапази“ ќе ни послужат како апликативен материјал за докажување на тезата дека еден мал локален фолклор, по својата содржина и суштина, се вклопува целосно во сликата на универзалната сказновидна матрица. Синтагмата „мал локален фолклор“ ја употребуваме условно, бидејќи сметаме дека не постојат мали и големи народи или мали и големи јазици, па следствено на тоа и фолклорот не можеме да го вреднуваме сразмерно со неговата просторна зафатнина. Фолклорното богатство што, со векови, го создавал македонскиот народ е толку големо колку што е големо и влијанието што го има и сѐ уште го врши врз градењето на македонскиот национален идентитет. Во таа насока, фолклорното богатство на Струмичкиот Регион е мало, но вредно камче што го прави мозаикот на македонската фолклористика богат, раскошен и многу вреден.

Волшебни приказни собрани во книгата „Араптази“ се необјавени сѐ уште, што ни дава право да кажеме дека за првпат на виделина излегуваат фолклорни артефакти ископани од тлото на Струмичкиот Регион. Импонира сознанието дека волшебните приказни што ги содржи книгата се собирани во периодот од 1970 до 2020 година, а сѐ уште не ја изгубиле својата свежина и актуелност. Во растојание од пет децении, Иван Котев создава импозантна архива на фолклорно богатство, ретка збирка на оригинални примероци, пандан на светската сказна. Фолклористичкиот материјал во книгата е подобен за истражување од многу аспекти: лингвистички, фолклористички, социолошки, историски, антрополошки, психоаналитички и слично. Нашата интерпретативна стратегија се темели на потребата да докажеме дека не постојат чисти и неконтаминирани форми на сказничните мотиви. Меѓусебните влијанија со етнички, културен или историски предзнак ја пресоздавале сказната, ја прилагодувале и видоизменувале, за да дојде до степен на постоење на повеќе варијанти на еден ист сказничен мотив. 
Сказната претставува axis mundi (Оската на светот) околу која гравитира(л) човекот, оној мал, трошен човек исплашен за себе и за заедницата, со погледот свртен кон небото, а со чувство дека под неговите нозе постои некој друг, чудесен свет, кој се опредметува во сказната. Тој имагинарен свет наеднаш станува мегдан за борбата на доброто и злото, простор што ги чува тајните на иницијацијата, односно созревањето на јунакот, оградена зона, локалитет на кој човекот со голи раце ќе почне да ја гради својата историја: „Ако ѝ ги поставиме вистинските прашања на бајката, таа праформа на раскажување може да ни ги даде и вистинските информации за суштината на книжевноста и суштината на човекот. Во раскошноста на нејзината игра и одделните варијанти, доаѓаат до израз најразновидните потреби и околности, кои се својствени за сите луѓе, но и за живата сестраност на: епохата, народноста, регионот, социјалните слоеви и личностите. Секоја одделна сказна има своја смисла и може да се проучува и да се толкува од различни гледни точки. Истовремено, сите сказни заедно во целост ни даваат една слика на човекот и светот“ (Лити, 2017, 119). Тргнувајќи од мислата на Макс Лити можеме да ја започнеме потрагата по скриените значења, кои ги носи во себе сказната. Феноменологијата на сказната се открива преку дешифрирање на нејзиниот семантички поттекст, кој секогаш носи скриени значења, суштински и каузално обусловени: „Сказната, како сегмент од колективната меморија, има референцијална и автореференцијална способност, своја текстуалност и метатекстуалност, своја драматика и драматургија“ (К'улавкова, 2018, 313). Сказната секогаш зборува преку симболите и метафорите. Тие, пак, се длабоко втемелени во архетипските слики што ги носи човекот, како дел од колективното несвесно. Со јазикот на поезијата можеме да кажеме дека дешифрирањето на симболите во сказната наликува на дешифрирање на скриените значења на метафората: „Метафората како фигура на сеќавање, која се групира врз основа на принципот на ресемантизација на знакот во новиот контекст, се препознава според принципот на аналогија/сличност меѓу различните, далечните и туѓите нешта, потсетување, барање на заеднички места на меморија, визионерско откривање на tertium comparationis (Ќулавкова, 2018, 78). Во сказната, речиси секогаш, аналогијата е во основата на: дешифрирањето на симболиката на мотивите, сижетите, функциите на ликовите, предметите. Митолошката семантика е појдовната точка во толкувањето на сказната затоа што космичките закони за устројството на човекот и светот во сказната се прелеваат кон социјалното и индивидуално искуство. Тотем-митовите за чудесните животни, за бракот и искушенијата, за стекнување необични нешта, најчесто волшебни предмети, за обредот на посветување, за патувањето во други светови и потрагата по лек за одредена болест, како и многу други мотивски конструкции, имаат свои реликти во сказната. Волшебните приказни од овој регион се согласуваат со универзалниот модел на сказната во која еден од најзастапените мотиви е задгробното патување на јунакот. Голем дел од нив изобилуваат со универзални мотивски конструкции и митологеми, кои се препознаваат во митологиите и верувањата на најстарите цивилизации. Фасцинира сознанието, колку овој регион, иако неистражен докрај може да даде квалитетна граѓa за потврдување на тезата 
дека претставите за задгробното патување на херојот, за Оската на светот, за ритуалната иницијациска смрт и повторното раѓање, имаат свои варијанти, кои се колективна своина на македонскиот народ.

Сказните од „Араптази“ нѐ воведуваат во едно возбудливо патешествие низ времето во кое нашиот предок созревал, еволуирал, за да дојде до еден степен на рационално сфаќање на светот во и околу него. Тој процес на матурација се чита низ кодовите во сказната, чија генеза Проп ја поврзува директно со обредите на посветување. Во овие сказни се среќаваат мотиви, кои се во најдиректна корелација со иницијацискиот обред: мотивот за децата оставени во шума, децата грабнати од шумскиот дух, престојот на јунакот во шумската куќарка, ликовите помошници (животните, бабата, дедото и сл.), отсекувањето делови од телото (најчесто прст), распарчувањето и повторното оживување, стекнувањето волшебен предмет, мотивот за грабната принцеза од страна на змејот, патувањето на јунакот во оностраното царство и сл. Симболиката во посочените мотиви нѐ носи секако до обредите на посветување, кои во суштина значат симболична смрт на јунакот, кој пак, по поминатите искушенија „повторно се раѓа“ и преминува во повисок социјален статус. Како апликација на поставените тези ке ни послужат две, од многуте приказни во книгата, кои, мотивски се допираат, а нивното семантичко толкување нѐ носи до моментот на пресликување на мотивите со универзалната сказновидна матрица. Првата приказна Детето јунак $u$ Арапино за своја основа го има мотивот на јунакот протеран од сопствената мајка, а втората, приказната Рокчето, мотивот на јунакот протеран од маќеата. И во двете приказни станува збор за прогонство на машки потомок, но во едната приказна протерувањето од домот го помага биолошката мајка, а во другата, маќеата. Според Проп, родителите не ги погубуваат своите деца сами, но оваа сказна од Струмичкиот Регион е пример за постоење и на таков мотив, редок и не многу застапен во фолклористиката. Факт, кој е интересен да се спомне во овој контекст, е времето на запишување на сказните. И двете сказни се запишани во последните неколку години, што претставува потврда дека фолклорот е најжилавата форма, која го поврзува човекот со неговиот духовен предок.

Во приказната Детето јунак и Арапино мајката останува вдовица со синот, момче различно од другите, поради белегот што го има. Момчето од сказната уште на самиот почеток е предодредено да има божествена моќ бидејќи е родено со три влакна на градите: У тиа три влакна била силата на детето. Ного било јуначиште, било големо јуначиште. Во шаманистичките претстави за јунакот, ваквите ликови се поврзуваат со ликот на змејовитиот човек, кој се одликува со голема сила и е предодреден да биде заштитник на заедницата. Симболиката на влакното е поврзана со машкоста и е добар знак доколку влакната ги има само на одредени делови од телото, како на градите, на пример. Ниту симболиката на бројот три не е случајна, таа е во директна врска со машкиот принцип. Меѓутоа, отсекувањето прамен коса (при крштевање, посветување во духовен чин или потстрижување при замонашување) според Проп значи стапување во нова заедница и врската со посветувачкиот обред е несомнена. При првото читање, отсекувањето на 
влакната, најдиректно се поврзува со мотивот на одземање на силата на јунакот. Негативниот принцип во приказната е претставен преку ликот на Арапинот, кој ѝ поставува услов на жената, мајката на детето: Ке те земам, ама ако го убиеш дет'то! К̈е го пратеш, вика, у една гора што се отвара и затвара, да ти црпне, вика, вода. Демек, лошо ти и н' тебе, ке ти црпне вода за да оздравееш! Ликот на мајката е најдиректно поврзан со иницијацијата бидејќ таа се обидува да ја раскине врската со машкиот потомок, да го протера од дома и симболично да започне неговото созревање. Сепак, мајката е таа што го осакатува духовно, односно му ги отсекува влакната, а Арапинот го извршува физичкото сакатење, со тоа што му го распарчува телото: Дет'то, коа легнува у курит'то, сечела му влакната. И, паѓа му силата. Арапино т'ва чекал. Излева ут пут кревето - рас - рас, на три дела го расечува, право у дисагите, зак'чил го на седлото на којно и го пушта. Распарчувањето и соединувањето на јунакот е еден од видовите на привремена смрт и во сказната многу често се среќава како момент во кој јунакот добива сила или некаква божествена моќ. Распарчување на телото, освен што има значајна улога во религиските сфаќања на човекот, според Проп, има улога и во сказната во која „расечувањето и оживувањето се извор на сила или услов за божествена моќ“ (Проп, 2011, 125).

Сепак, во приложената сказна распарчувањето се случува како чин на привремена смрт и повторно раѓање, во рамки на процесот на иницијација. Привремената смрт е позната во шаманската обредна практика и постојат запишани сведоштва за тоа. Откако ќе го прифати шаманскиот повик, идниот шаман чувствува дека е препуштен на божествените сили и осуден на неминовна смрт. Таа смрт е симболична и тој душевен хаос во кој запаѓа идниот шаман е знак дека световниот човек се распаѓа и дека во тој момент се раѓa нов човек. Мирча Елијаде наведува примери на иницијација кај јакутските шамани, кои за време на обредот се исечени на парчиња, обред што трае седум дена, време за кое шаманот наликува на мртовец оставен на некое осамено место. Слични примери наведува и Владимир Проп во книгата „Историските корени на волшебната приказна“. Од аспект на психоанализата, Јунг, иницијацијата ја толкува како внатрешно патување, патување до Себството или средба со самиот себе. Тоа патување го поддржува цикличното движење, патувањето завршува на местото, каде што почнало, односно протераниот јунак се враќа повторно во домот, најчесто поради одмазда. Јунакот, кој е распарчен, е ставен во дисагите на коњот, бива соединет од бабата, оздравен од неа за на крајот, по три години, да се врати и да ја изврши одмаздата: да ги убие мајката, Арапинот, но и четириесетте мали Арапчиња. „Познат е ефектот на кружница, односно движење по пат на додавање, надополнување, кое личи на мандала, што, според Јунг, е типичен образец во сказните кога станува збор за процесот на преобразба“ (АнастасоваШкрињариќ, 2011, 170). Тој процес на иницијација или индивидуализација успешно се заокружува доколку јунакот успее да дојде во контакт со женскиот принцип, односно да се ожени (како во нашата сказна во која ликот на бабата е најдиректно вклучен во поврзувањето на двата принципи и успешната иницијација). Ликот на бабата се јавува и претходно во сказната, 
како лик што го предупредува момчето за планот на неговата мајка и Арапинот. При извршувањето на трите тешки задачи, ликот на коњот е постојано со момчето и ја има улогата на лик помошник и закрилник. Но, кога ќе се случи распарчувањето, коњот ја добива улогата на психопомп или преносител на душата на привремено мртвото момче, до куќата на бабата. Кога Арапинот ги става распарчените делови во дисагите на коњот, тој заминува во шумата во куќата на бабата, каде што веќе претходно бил: Којно, дека бил последен пат, па там оде кај бабичката. И она, ка го видела, почнала да го оплакува и да зборува: „А бре синко, нели ти кажах оти мајка ти се лаже со Арапино, оти Арапино сака да те утепа за да а земе!? Арно ама, дими знајала ного лекове, била лекувачка - го соединува дет'то и три гудини кај неа било. Они дека биле, и он там! По тригодишниот престој кај бабата, јунакот се враќа за да ја изврши одмаздата со шиирто, пушка $и$ пиштол (што му ги дава бабата). Момчето ја извршува одмаздата со тоа што ги пали затекнатите читиријсе Арапчина, а ги убива мајката и Арапинот. По завршената иницијација момчето е подготвено за женидба, се враќа кај бабата за да одбере една од трите ќерки за жена.

Рокчето е сказна, која, во основата, го има мотивот маќеа - посинок. Отфрленото момче за свој помошник го има волот во чиј рог има храна во изобилие. Волот ќе се спаси од лошата маќеа, која бара да биде заклан, но не и од еленот, кој е млад и силен и всушност е од неговиот свет. Волот, како животно помошник на јунакот, не може да ја совлада силата на соперникот од неговиот свет, но затоа на момчето му го остава својот рог: Отишол до мртвиот Сивчо, го одвртува рогот и од него излегле роеви инсекти. Тие се претвориле во овци, говеда, кози - сѐ! Одмах се створиле овчаре, говедаре, козаре... Детето станало богат човек. И така, чувал стока. Се оженил, одимал деца и си живеел среќно. Најстарата форма на волшебни предмети, според Проп, се делови од животното. Многу често во сказните се среќаваме со волшебните предмети, како што се: кожата на животното, забите, ноктите, крзното и секако влакната и пердувите, како најзастапени. Волот Сивчо, во оваа сказна, се јавува како животно помошник и животно дарител, но на своја иницијатива. Не станува збор за благодарно животно, кое поради тоа што било поштедено од убивање, му помага на јунакот. Едноставно, волот е лик помошник, кој е симбол на „добрината, смиреноста и мирољубивата сила, а за неговата мистична симболика се потенцира следното: ликот на волот е симбол на силата и моќта, а неговите рогови се симбол на заштитничката и непобедлива сила, рогот како симбол на машката сила“" (Chevalier, Gheerbrant, 1987, 761-762). Од друга страна, пак, роговите се симбол на плодноста, која се препознава при читање на површинскиот слој на посочената сказна. Меѓутоа, во симболиката на роговите, Јунг пронаоѓа една подвоеност: „со својот облик и продорност роговите го предочуваат активниот машки принцип, а со својот отвор во облик на лира, потсетуваат на женскиот принцип. Спојувајќи ги овие два принципи во обликување на својата личност, личноста постигнува зрелост, рамнотежа и внатрешен склад“ (Chevalier, Gheerbrant, 1987, 564-565). Волот умира во борба со еленот, кој е помлад и посилен. Но, по неговата смрт остануваат роговите од кои треба да се оплоди новиот живот на јункот, кој 
успешно ја завршува иницијацијата. При обредите на посветување, момчињата добивале власт на животните тогаш кога добивале делови од животното.

Овие примери на сказни од Струмичкиот Регион покажуваат дека реконструкцијата на сказничните мотиви, со помош на семантичкиот пристап, го разоткрива естетизираниот живописен и колоритен поттекст на сказната како универзален културен идентификатор.

\section{Прилози}

\section{ДЕТЕТО ЈУНАК И АРАПИНО}

Живејали си маж и жена. Имале едно машко дете. Умрел мажо и устанала сама жената со детето. И, р'стело т'ва дете, ст'нало ергенче, маж на седум - осумнајсе гудини. Ергенче за мерак!

Арно ама, жена к'ту жена, мајката през тоа време се з'лажува со еден Арапин. И, еден ден, дет'то ка се бајнало, Арапино забележува оти на градите има три влакна. У тиа три влакна била силата на детето. Ного било јуначиште, било големо јуначиште. Арапино се уплашил! Шо ќе направе, к’жал т’ка на мајката:

- Ке те земам, ама ако го убиеш дет'то! Ке го пратеш, вика, у една гора што се отвара и затвара, да ти црпне, вика, вода. Демек, лошо ти и н’ тебе, ќе ти црпне вода за да оздравееш!

И, мајката го накарува дет'то:

- Сине, ногу сум болна! Оди, вика, у таа планина што се отвара и затвара. Коа ќе се отворе планианта, црпни вода и излези! (Па, нејќела да го утепа дет’то.) Црпни и излези!

Ох, како ќе биде!?

И, ништо. Оде.

Дет'то ного а сакало мајка му. Оде у планианта. Црпнува вода и с'с којно излева! силно!

Арапино ного се наљутил, ама и се уплашил. Знајал дека дет'то а ного

Смислил друг план.

- Ќе го пратеш дет'то, вика на мајката, у фиљан село, една баба има ного убави лубеници, лековити. Нека ти дунесе една лубеница!

Мајката му кажува на дет'то:

- У т'ва и т'ва село имало една баба, имала лековити лубеници. Оди д' ми донесеш една, ќе апнам и ќе уздравеам!

И, дет'то оде. Арно ама, таа баба била некоа гатачка, гледачка била. Имала три керки.

Дуваѓа дет’то кај неа и ѝ к’жал за што и како е дојден кај неа. Бабата го погледнала и му к'жала т'ка:

- Чедо, мајка ти те лаже с'с Арапино! Он ќе ја земе ако те утепа тебе! Дет’то не поверувало. „Е, е, мама ќе ме утепала, како да не!“ - си мислело.

- Дај ми, вика, лубеница да ѝ уднесам на мама! 
- Арно, ќе ти дадам, ама да се пазеш!

Дет'то се враќа и ѝ уднесува лек на мајката. Арапино се уплашил. Со сите сили настојувал мајката да го отепа дет'то. Трите влакна на градите не му дават мира. „Ке мора да се сечат“, решил Арапино. И, еден ден ѝ вика на мајката:

-E, вика, знааш саа шо ќе напрааме, вика. Јас ќе се скриам пут кревето. Ти, оти ного го сакаш, ќе го избајнеш. Ке земеш ножници и ќе му ги сечеш влакната. Другото е моја работа!

Мајката така н'прила. Дет'то, коа легнува у курит'то, сечела му влакната. И, паѓа му силата. Арапино т'ва чекал. Излева ут пут кревето - рас pac, на три дела го расечува, право у дисагите, зак'чил го на седлото на којно и го пушта. Којно, дека бил последен пат, па там оде, кај бабичката. И она, ка го видела, почнала да го оплакува и да зборува: „А бре синко, нели ти кажах оти мајка ти се лаже со Арапино, оти Арапино сака да те утепа за да а земе!?“

Арно ама, дими знајала ного лекове, била лекувачка - го соединува дет'то и три гудини кај неа било. Они дека биле, и он там!

Едно време дет'то се свестило и пита:

- Бабо, дек' сам?

- А, бре синко, нели ти кажувах оти мајка ти се лаже с'с Арапино и оти сакат д’ те утепат? За да го земе Арапино, тебе те утепаа. Ти, вика, мене не ме послуша!

Дет'то у мислите пак се занесува, не е дип уздравело. И, вика:

- Јас ќе си одам! (Сакал да ги убие мајка му и Арапино.)

- Слушај ти сега јас шо ќе ти кажам! Ке си одеш, ама како прво, јас имам три ќерки: гулема, средна и малечка. Првата ќе ти фрле лубеница сто метра далеку от тебе. Ако ја фатеш, ќе си одеш, ако не - не!

Ох, тоа не може да ја фате лубеницата. Оште било ного слабо. Седе оште една година.

Фтората година па кажал:

- Ке си одам!

- Не! Фтората ќерка ќе ја фрле лубеницата двеста метра. Ако ја фатеш, ќе си одеш, ако не - не! треба.

Ох! Не можел да ја фате лубеницата. Оште не бил оздравеен како шо

Трет’та гудина веќе се осеќа маж! Врнала му се сиалта!

- Бабо! - вика, јас ќе си одам! Ништо не ме спречува! Јас мајка ми ќе ја уништам!

- Добро, синко! Ама, ќе треба да ја фатеш лубеницата. Трет'та ќерка лубеницата ќе ја фрле триста метра. Ако можеш да ја фатеш, јас не можам да те сопрам! Оди!

Најмаленката фрља а лубеницата. Дет’то рипнува и фајќа а!

Тргнува да се оде. Бабата му вика:

- Ке земеш, вика, шпирто, пушка и пиштол!

Дет'то на којно и - та̀ при мајка му.

А за тиа три гудини мајката на дет'то рудила и гледала читиријсе Арапчина. 
Оде си дома и - шо ќе виде! На една ругузина читиријсе Арапчина!

- Дека а мајка ви?

- Дома!

- Татко ви?

- Дома!

Извадува шпирто и ги изгорува децата. Флева у собата на мајка му.

Оште на врат'та, коа усетил Арапино оти нешто горе, ојдел да виде. Ка го сретело дет'то, извадило пиштоло - паат! Трипати го застрелал и Арапино паѓа мртов на врат'та. Флева при мајка му:

- Мајко, ти што ми н'први!? За Арапино да го земеш, ме пуништи! У коа ќоше ќе з' станеш да те застрелам? Сакаш у т’ва, сакаш у т’ва!

- Аман, синко!

- Нема аман!

3'ст'нала у едно ќоше. Дет'то искарува пиштоло - пат! Пат! Пат! трипати пукал, утепува а.

Се врајќа кај бабата.

- Шо н'при, бе, синко?

- Читиријсе Арапчина за т’ва време, бабо, вика, мајка ми и имала с'с тај Арапин! Арапчианта ги изгурех, мајка ми га утепах, Арапино го утепах, вика. Саа, вика, шо ќе праам?

- Коа ќерка сакаш, таа га земи, вика, фнуци да имам!

И, ја зима најмаленката ќерка и си живејале.

Толко а.

Забелешка: Приказната е необјавена. Снимена е на 17.12.2015 година во с. Петралинци, Струмичко. Информатор: Дана Станојска од с. Петралинци, родена 1954 год. Има завршено 8 одд. Снимил и дешифрирал Иван Котев.

\section{РОКЧЕТО}

Имало едно време во едно село маж и жена. Имале едно дете, многу послушно. Уште од малечок помагал и на мајка му, и на татко му. Арно ама, немало среќа да расте со мајка си, која многу ја сакало. Таа се разболела и набргу умрела. Останале сами со татко му. По извесно време таткото се преженил и одимал и други деца од втората му жена. Маќеата повеќе ги гледала своите деца - пубаво ги облекувала, хранела, не ги праќала на тешки работи. Сите работи ги извршувало детето од првата жена. Ги пасел говедата низ планинските ливади. Цел ден трчало по воловите изгладнето, босо, сокинато. Маќеата во торбичката му ставала само по неколку суви корки леб. И во куќата, кога биле на синијата, било и тоа. На нејзините деца ќе дадела топло млеко, пржрно сирне и јајца, убав леб, а на тоа дете - некоја коричка леб и нешто што останало од претходните јадења.

Детето било многу тажно, но и налутено. Еден ден, при таква ситуација, кога пак му дале некоја корка, а во киселата матеница ставила и жабичка внатре, во чинијата. Толку го мразела! Да му туре жаба у чинијата! Многу му се нажалило на детето. Зима, ја заменува чинијата и ја дава на другото дете, од 
природените. Набрзина го изел слаткото јадење и тргнал со воловите кон планината.

А кога детето на маќеата почнало да јаде, не му се аресува јаденето. А кога видело, извикало:

- У, у, у! Нешто ме гледа од паницата!

Што ќе е тоа? Жаба! А она знае дека детето ја замнило чинијата. Пудберала го това дете - ни јадене, ништо тој ден. Цел ден со стоката, сега и без коричка леб. Му се нажалило и почнало да плаче. А имало еден стар вол, сив, Сивчо го викале. Ка видел оти детето плаче, му се приближува, и, прозборил воло. Вика:

- Што плачеш?

- Така и така, вика и му раскажало на воло се́ што се случило, како повеќе е гладен отколку најаден, повеќе е смрзнат отколку стоплен. Кажува на воло и с'зички течат.

Сивчо слушал, слушал и рекол:

- Дојди кај мене!

Детето отишло до него.

- Одврти го рогот од твојата страна! сакаш!

Како на винт рог. Одвртува го и - унатре - што, о, о, о! - храна каква

- Само ќути, вика, не збори на никој, вика, ти секогаш добро ме пасеше и пазеше.

И така, денес, утре, другиден, маќеата забележала дека детето иако не зима храна од дома, добро напредува. И сега што ќе праве? Скришно оди по него, да виде на кој начин он денот го мине, каде се хране. Од дома не зима храна! Видела како детето го одвива рогот на Сивчо и како богато се храни.

- О, о, о, ооо! Еве каде била работата!

Дошла дома и се направила болна. Мажот ѝ се вратил од работа.

- Што е, што си легнала?

- Болна сум, така и така ми се сонй, вика, сивио вол да го заколеме, курбан да го раздадеме на селането...!

Уш ќе оздравела. И тој, што ќе направи. Се согласил воло да го заколе. Арно ама, моабето го слушало дет’то. Чуло се́. Не спијало. Чујало дека воло ќе го кољат!

Кога сабаалето ги пуштил воловето и ги откарал да ги пасе, оно заплачало, дет'то заплачало и воло Сивчо, се приближува до него и вика:

- Што е бе, вика, што плачеш?

- Е, Сивчо, вика, маќеата така и така рече, ќе те земат, ќе дојдат да те земат, ќе те закољат!

A тоj:

- Не се плаши, вика. Татко ти ка ќе дојде, јас ќе бегам. Не давам да ме заколе. А ти ќе кажеш: „Тате, дај ми важето, јас стално го чувам волот, на мене ќе биде мирен сигурно, јас ќе го наоглавам, ти ела земи го!“‘

И така направиле. Дојдел едно време татко му.

- Каде пасе Сивчо?

- E, таму! 
Отишол татко му. Тој бега. Ваму-таму, да го наоглави Сивчо, не може! И тава дете кажало тогај. Вика:

-Дај јас ќе го наоглавам, јас го чувам стално, помирен ќе биде на мене.

-Добро!

Дава му важето. Детето го земало и оде кај воло.

- Сега качи ми се на грбо и да бегаме!

И дет'то скокнало на грбо на воло и му ја спраштиле на бегане.

Таткото:

- Стој! Стој! - ама побегнале.

Побегнале преку една планина. Нашле убави ливади и таму си живејале. Ама, не за долго. По извесно време се појавува еден елен. И вика:

- Што го пасете мојот реон?

Започнува борба. Првиот ден борба, борба, и на елено и на воло пејна тече од устата. Никој не може да победе. Вторјо ден, па така. Третјо ден веќе кажал воло на тава дет'то:

- Јас не мож' да издржам. Тој е многу млад, елено, ќе ме утепа, вика. Но ти, после, вика, ти ќе земеш, ќе го одвртеш рого, ќе го земеш, вика, с'с тебе, ќе одеш негде, ќе заградеш штали, трла, од рого ќе излезат инсекти и ќе се претворат во волове, овци, којне... Ке ги гледаш и богат ќе бидеш!

И така, на третиот ден доваѓ елено и започнала борбата. Се бориле, се бориле, но волот бил победен и умрел. Детето многу се натажило, но го послушал волот и запомнал сѐ што му кажал. Така и направил. Отишол до мртвиот Сивчо, го одвртува рогот и од него излегле роеви инсекти. Тие се претвориле во овци, говеда, кози - сѐ! Одмах се створиле овчаре, говедаре, козаре... Детето станало богат човек. И така, чувал стока. Се оженил, одимал деца и си живеел среќно.

Толку е.

Забелешка: Приказната е необјавена. Снимена е на 21.10.2016 год. во Струмица. Информатор: Борис Ефтимов, роден 1940 год. во с. Сачево, Струмичко. Има завршено Воена академија. Сега е воен пензионер. Снимил и дешифрирал Иван Котев.

\section{ЛИТЕРАТУРА}

\section{Кирилични изданија}

АНАСТАСОВА-ШКРИњАРИК,, Н. (2011). Триножникот на Цепенков $и$ каучот на Фројд. Скопје: Македоника литера.

АНАСТАСОВА-ШКРИњАРИЌ, Н. (2017). Фолклорологија. Скопје: Табернакул.

БОРЕВ, Ј. (2011). Енциклопедија на естетиката и на теоријата на литературата. Скопје: Македоника литера.

ЛИТИ, М. (2017). Европската сказна - форма и суштина. Фолклорологија, 2017, 100-120. 
ПРОП, В. (2011). Историски корени на волшебната приказна. Скопје: Македоника литера.

ПРОП, В. (2009). Морфологија на сказната. Скопје: Македоника литера.

ЌУЛАВКОВА, К. (2018). Балкански наративи. Скопје: Три.

\section{Латинични изданија}

CHEVALIER, J. GHEERBRANT, A. (1987). Rječnik simbola. Zagreb: Nakladni zavod Matice Hrvatske.

MATIĆ, V. (1972). Zaboravljena božanstva. Beograd: Prosveta.

MATIĆ, V. (1979). Psihoanaliza mitske prošlosti I, II. Beograd: Prosveta.

Ana Vitanova-Ringacheva

\section{THE SEMANTIC CONTEXT OF THE LOCAL STORY IN ACCORDANCE \\ WITH THE UNIVERSAL MODEL OF THE STORY MATRIX \\ (based on examples from the unpublished book "Araptazi" - magical folk stories from Strumica by Ivan Kotev)}

\section{Summary}

Mythological semantics is the starting point in the story interpretation because the cosmic laws of the human's structure and the world in the story flow into the social and individual experience. Totem myths about miraculous animals, marriages and temptations, unusual things, most often magical objects, for the consecration rituals, traveling to other worlds, and the search for a cure for a specific decease and many other motivational constructions have their relics in the story. The magical folk tales are the most colorful, motivational overwhelmed and most splendid units of folklore and they, besides the animal tales, are considered the oldest kind of oral prose. The region of Strumica and its surroundings is rich with folkloric material, especially magical folk tales that, by their structure, motivational construction and age, are reflected in the universal model of world story. 